\title{
Improving China's food and environmental security with conservation agriculture $^{\dagger}$
}

\author{
Hongwen $\mathrm{Li}^{\mathrm{a}}$, Jin $\mathrm{He}^{\mathrm{a}}$, Zareen Pervez Bharucha ${ }^{\mathrm{b}}$, Rattan $\mathrm{Lal}^{\mathrm{c}}$ and Jules Pretty ${ }^{\mathrm{d} *}$ \\ ${ }^{a}$ College of Engineering, China Agricultural University, Beijing, 100083, China; ${ }^{b}$ Department of \\ Sociology, University of Essex, Colchester CO3 4SQ, UK; ${ }^{c}$ School of Environment and Natural \\ Resources, Ohio State University, Columbus, OH, USA; ${ }^{d}$ School of Biological Sciences, University of \\ Essex, Colchester $\mathrm{CO} 34 \mathrm{SQ}$, UK
}

China has achieved impressive increases in agricultural output in recent decades. Yet, past approaches centred on a growing use of fertilizers, pesticides, fuel and water are not likely to achieve the required $30-50 \%$ additional increases in food production by mid-century. We show that efficiencies of production are falling and the costs of environmental harm are increasing. Agricultural innovations that improve natural capital are urgently needed. Conservation agriculture (CA) is now practised on $>8$ Mha in China and is offering promising prospects of both enhanced yields and environmental services. Our meta-analysis of 60 papers with 395 observations in China shows notable benefits from CA. Mean yield increase was $4.5 \%$ or $263 \mathrm{~kg} \mathrm{ha}^{-1}$ for wheat, $8.3 \%$ or $424 \mathrm{~kg} \mathrm{ha}^{-1}$ for maize, and $1.65 \%$ or $250 \mathrm{~kg} \mathrm{ha}^{-1}$ for rice. In 34 datasets from 22 published papers (experimental duration: $2-17$ years), 26 datasets $(76.5 \%)$ show that $\mathrm{CA}$ increased yield and soil organic carbon (mean SOC increase of $>3 \mathrm{~g} . \mathrm{kg}^{-1}$ in $0-10 \mathrm{~cm}$ soil depth) when compared with traditional tillage. Key priorities for the spread of more sustainable forms of agriculture in China are national policy and financial support, better coordination across agencies, and better extension for farmers.

Keywords: agricultural sustainability; China; conservation agriculture; sustainable intensification

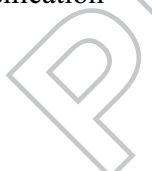

\section{Food and consumption nexus}

Despite great changes in agricultural systems worldwide and consequent increases in food production in recent decades, the world faces unprecedented challenges during the twenty-first century (FAO, 2016; Foresight, 2011; Lu, Chadwick, Norse, Powlson, \& Shi, 2015). Three interacting challenges are: continuing food insecurity for nearly 800 million people, increased demand arising from changes in consumption patterns and growing total numbers of people and diminishing stocks of natural capital (Godfray et al., 2010; Pretty, 2013). China exemplifies these interactive challenges. Land and policy reforms combined with rapid adoption of modern agricultural practices has increased both total and per capita food production at a rate greater than in the world's other key regions (Table 1). From 1990 to 2012 net agricultural production increased

\footnotetext{
${ }^{\dagger}$ This paper was handled for IJAS by Associate Editor, Colin Sage, independently of the Chief Editor and Assistant Editor (both authors on this paper). Four anonymous referees commented on the paper, and the revised version was approved by the Associate Editor before the paper was formally accepted for publication in IJAS.
} 
Table 1. Changes in net and per capita agricultural production $(\%, 1990-2012)$.

\begin{tabular}{lrr}
\hline China & +150 & +109 \\
North America & +35 & +7 \\
Europe & -16 & -12 \\
Africa & +103 & +14 \\
World & +65 & +22 \\
\hline Source: FAO (2015). & &
\end{tabular}

by two-and-a-half fold, per capita food production doubled; population increased, yet agricultural production increased even faster.

Over the same period, consumption patterns have changed, putting pressure back on food security. The proportion of the world population who are undernourished declined from $24 \%$ to $10.6 \%$ between 1990 and 2014 (Africa from $28 \%$ to $20.5 \%$; India from $24 \%$ to $15.2 \%$ ) (FAO, 2015). Meat consumption per capita (a proxy for the degree of ecological inefficiency in the food system) increased by $26.3 \%$ worldwide, with the fastest growth in China and Brazil (Table 2). Impacts on agricultural and non-agricultural land also extend globally across transnational supply chains. Demand in China for animal feedstuffs, for example, places new pressures on South American, particularly Brazilian agricultural and non-agricultural ecosystems (Bharucha 2014). Further, direct and indirect pressure on agricultural production will come from climate change and depleted ecosystem services fundamental to agricultural success (Costanza et al., 2014).

By 2050, world population is projected to grow to 9.7 billion, necessitating an increase in food production by some 70\% (FAO, 2015; Foresight, 2011; Godfray et al., 2010; Tilman, Balzer, Hill, $\&$ Befort, 2011). China's population is predicted to grow by 100 million to 1.46 billion. Given a reduction target to reduce the number of undernourished people from 144 million to zero and the future changes in diets and growing population, China will need to increase food supply from domestic sources and/or from imports by $30-50 \%$ by $2040-2050$ (NBS, 2013, 2014). A key challenge centres on policy choices: will past agricultural practices that have brought food production growth continue to succeed, or will new approaches centred on agricultural sustainability be essential (Pretty \& Bharucha, 2014; Royal Society, 2009; Zheng et al., 2014)?

\section{Declining efficiencies and increasing environmental costs}

Improvements in agricultural output in China have been driven by increases in consumption of four factors of production: fertilizers, pesticides, fuel and water (Table 3). At the same time,

Table 2. Changes in per capita meat consumption (kg, 1990-2011).

\begin{tabular}{lcrr}
\hline & $1990(\mathrm{~kg})$ & $2011(\mathrm{~kg})$ & \% change \\
\hline China & 24.8 & 57.5 & +131.9 \\
USA & 112.7 & 117.6 & +4.3 \\
UK & 72.0 & 82.5 & +14.6 \\
Brazil & 49.4 & 93.0 & +88.3 \\
India & 4.1 & 4.2 & +2.4 \\
World & 33.4 & 93.0 & +178.4 \\
\hline
\end{tabular}


the efficiency of these resources has declined: only the water use efficiency (WUE) for grain production has increased (Figure 1). Some of the required increases in food production could come from further increases in use efficiency of these factors of production, but with a declining marginal efficiency, costs to farmers and the wider economy will rise (Norse \& Ju, 2015). Concurrently, Chinese arable land area is slightly changed and limited in supply: over 2009-2013 the arable land area changed from 135.38 Mha to 135.16 Mha (MOLR, 2010-2014). Further increases in land area for grain cropping are not a viable option. Further development would move into less favourable arable land and cause a loss of ecosystem services from the conversion of valuable habitats and natural systems. At the same time, arable land is being lost to urban encroachment (Su, Jiang, Zhang, \& Zhang, 2011).

A further cost arises from direct negative impacts of some agricultural practices on natural capital and human health. China is now the largest consumer of pesticides worldwide, more than tripling use since 1990 to 1.81 billion $\mathrm{kg}$ of the current world annual total of 3.5 billion $\mathrm{kg}$ (FAO, 2015; NBS, 2013). Evidence from integrated pest management (IPM) projects in Asia and Africa shows that at least $50 \%$ of pesticides applied (by weight) are overused, resulting in each $\mathrm{kg}$ of active ingredient imposing US\$4-\$19 of external costs to the environment and human health (Norse, Li, Jin, \& Zhang, 2001; Pretty \& Bharucha, 2015). Fertilizer use in China has increased by $227 \%$ to $58 \mathrm{Mt}$ annually (Table 3 ), yet not all applied nutrients are taken up by plants or microbial communities and thus escape and contribute to the costly eutrophication of aquatic ecosystems (Norse et al., 2001) and nitrous oxide emissions (Yu, Zhao, \& Jia, 2015). Soil degradation affects agriculture's ability to continue to be productive as well as adversely impacting ecosystems. In China, a total of 295 Mha of land is prone to accelerated soil erosion (MOEP, 2014), and in some principal rivers, annual soil sediment losses are normally over $300 \mathrm{Mt}$ (Table 4). For arable lands, topsoil rich in organic matter and nutrients is usually the first to be eroded, thus resulting in considerable flux of carbon to the atmosphere and negative impacts on soil productivity (Wang, Oenema, Hoogmoed, Perdok, \& Cai, 2006).

115 The challenge is substantial: China must produce 30-50\% more food during the next 25-35 years, yet it must also find ways to adopt agricultural innovations that improve natural capital and ecosystem services. Sustainable intensification (SI) is defined as a process or system where yields are increased without adverse environmental impact and without the cultivation of more land. The concept is thus relatively open, in that it does not articulate or privilege any particular vision of agricultural production (Conway, 1997; Garnett et al., 2013). It emphasises ends rather than means, and does not predetermine technologies, species mix or particular components of agroecological or agronomic design.

Thus, SI can be distinguished from earlier conceptions of 'agricultural intensification' as a result of its explicit emphasis on wider environmental and health outcomes. It is often achieved from shifts in the factors of agricultural production (e.g. from use of fertilizers to nitrogen-fixing legumes; from pesticides to emphasis on natural enemies and on creating disease-suppressive soils with favourable micro-biota (Mendes et al., 2011); from ploughing to no-till or NT)

Table 3. Changes in four factors of production, China.

\begin{tabular}{lccc}
\hline & Current annual use & Increase over period (\%) & Years \\
\hline Fertilizers & $58.4 \mathrm{Mt}$ & +227 & $1990-2012$ \\
Pesticides & $1.806 \mathrm{billion} \mathrm{kg}$ & +236 & $1990-2012$ \\
Fuel & $36.5 \mathrm{Mt}$ & +64 & $2000-2013$ \\
Water & $392 \mathrm{Mt}$ & +4 & $2000-2013$ \\
\hline
\end{tabular}




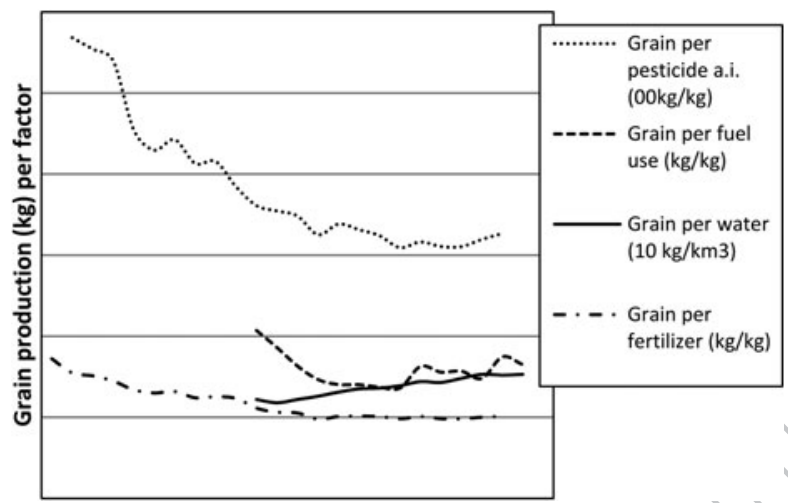

Figure 1. Efficiency of grain production for different factors, China (1990-2013).

Notes: Pesticides include all herbicides, insecticides and fungicides; grains include all major and minor grains.

Sources: calculated from MOA (2000-2014); NBS (2013, 2014).

rather than simply intensifying the use of existing inputs. A number of approaches have been identified for the SI of agro-ecosystems, including crop variety improvements, IPM, management intensive rotational grazing systems, integrated nutrient management (INM), CA and agroforestry systems (Barzman et al., 2014; Ellis and Wang, 1997; Pretty \& Bharucha, 2014, 2015; Shi, 2002; Smith, 2013). Here, we analyse the practice and potential of changes in soil tillage derived from plot experiments across China to deliver scale benefits in China.

\section{Conservation agriculture in China}

CA comprises management that minimises or eliminates soil tillage, maintains year-round soil cover and includes cover crops in rotations, and uses INM (Lal, 2015a, 2015b; MOA, 20002014). The aim is to maintain an optimum environment in the root zone in terms of water availability, soil structure and biotic activity (He et al., 2012; Kassam, Friedrich, Shaxson, \& Pretty, 2009; Lal, 2014). CA practices evolved in part as a response to the severe soil erosion that devastated the US Midwest in the 1930s; now CA systems are practised across a range of agroecological conditions, soil types and farm sizes, and covered 155 Mha globally in 2014 (Kassam et al., 2014). Adoption varies by region: CA covers $69 \%$ of arable cropland in Australia and New Zealand, $57 \%$ in South America, $15 \%$ in North America, but only $1 \%$ in Europe. The area under CA in China has grown rapidly from 0.5 Mha to 8.4 Mha over 2000-2014

Table 4. Annual soil sediment losses from the principal rivers in China.

\begin{tabular}{lcc}
\hline & \multicolumn{2}{c}{ Annual average } \\
\cline { 2 - 3 } River & $1950-1995$ & 2013 \\
& Total amount of erosion (Mt) & Total amount of erosion (Mt) \\
\hline Yangtze River & 23870 & 550 \\
Yellow River & 16000 & 830 \\
Zhujiang River & 2200 & 670 \\
Songhuajiang River & 190 & 320 \\
Liaohe River & 1530 & 340 \\
Talimu River & 1300 & 1040 \\
\hline
\end{tabular}


(Figure 2), driven in part by policy recognition in the 2005 No 1 Document that advocated reform of traditional farming practices and the promotion of $\mathrm{CA}$, formally recognising that $\mathrm{CA}$ can reduce soil erosion, restore degraded soils and improve productivity in a range of cropping systems.

In comparison with conventional tillage systems, CA practices can produce yield increases ranging from $10 \%$ to $120 \%$ (Kassam et al., 2014; Lal, Griffin, Apt, Lave, \& Morgan, 2004). One meta-analysis of 120 crops in 63 countries, however, showed that no-till (NT) systems largely resulted in yield declines, and concluded that performance was highly context dependent (Pittelkow et al., 2015b) and often dependent on nitrogen application or fixation (Lundy, Pittelkow, Linquist, Liang, \& van Groenigen, 2015); another found yield increases in China of the order of $4.6 \%$ (MOA, 2000-2014). Beneficial impacts in terms of resource efficiency include reduced need for fertilizer over time, lower runoff and increased resilience to pests and diseases. These changes can result in cost savings to farmers, which combined with yield increases, may translate to significant financial benefits relative to conventional ploughing. Comparisons between conventional tillage and reduced or NT systems have found higher soil organic carbon (SOC) concentration, lower emissions and improved soil quality (He, Kuhn, Zhang, Zhang, \& Li, 2009; Li et al., 2007; Zhang, Lal, Zhao, Xue, \& Chen, 2014). Nonetheless, scientific debate highlights a number of challenges, centring on the need for site-specific adaptation of CA packages (Kirkegaard, Conyers, Hunt, Kirkby, \& Watt, 2014), the applicability of CA to some smallholder systems (Giller, Corbeels, Nyamangara, Triomphe, \& Affholder, 2011), and the trade-offs involved in scaling to large numbers of farmers (Pittelkow et al., 2015a; Powlson et al., 2014).

We now analyse the evidence on the impacts of CA in China on crop productivity and environmental services, focusing on (i) agricultural productivity; (ii) erosion control, moisture conservation and WUE; (iii) carbon sequestration in soils.

\subsection{Methodology}

3.1.1. Meta-analysis of CA's effects on crop yields

Data collection: No tillage and reduced tillage form a component of a suite of practices termed conservation agriculture (CA), comprising retention of crop residues on the soil surface and

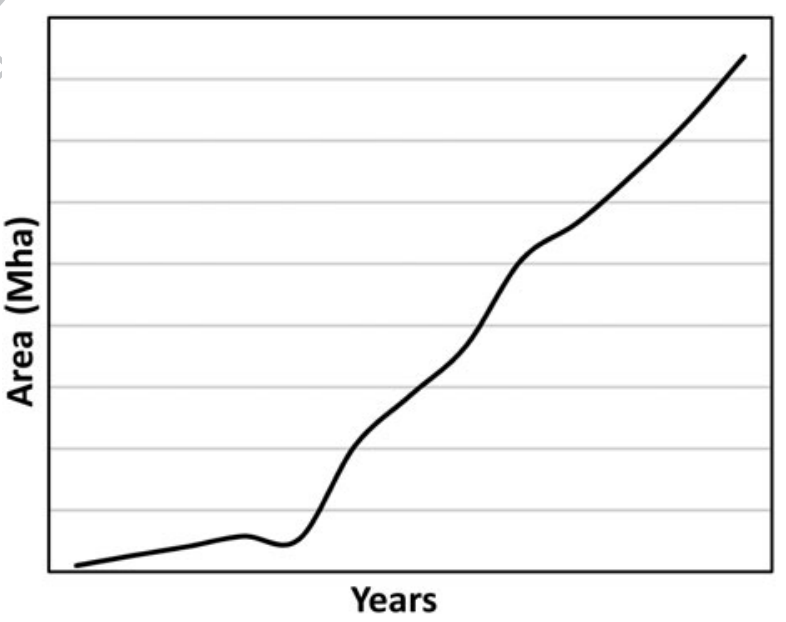

Figure 2. Agricultural area under conservation agriculture, China (Mha). 
diversification of cropping systems based on use of cover crops in addition to no tillage or reduced tillage. In our analysis, NTSR refers to no tillage with straw retention. If published papers did not clearly indicate whether straw was covered or removed, we have used the term no tillage (NT): CA thus includes NT and NTSR. We comprehensively searched the peer-reviewed literature for publications investigating the effects of CA on crop yields from the Science Citation Index of the Institute for Scientific Information and Chinese Journal Net full-text database (CJFD). Search terms included 'tillage', 'no till', 'zero till', or 'conservation agriculture' in the article title and 'yield' in the article title, abstract, or keywords. This search was screened on the basis of the following criteria: (i) studies had to represent field experiments containing side-by-side comparisons of CA (NT, NTSR) and traditional tillage practices in China; (ii) the crops are wheat, maize and rice, and crop yields were reported; (iii) location of the experiment was stated; (iv) the field experiments had an experimental duration of at least 2 years. In total, 60 published papers were included, consisting of 75 paired trials and 395 observations.

Data analysis: In research domains where the outcome is measured on a physical scale and is unlikely to be zero, the ratio of the means in the two groups (the response ratio R) might serve as the effect size index. The effect size $\left(M_{i}\right)$ was calculated as the natural logarithm of the response ratio (R), which is the crop yield under CA practices (NT and NTSR) divided by that under CT. Studies lasting several years or seasons were represented by several observations as annual and seasonal yield, respectively, in the dataset. Studies were weighted by observation numbers: $W_{i}$ $=n$, where $W_{i}$ is the weight for the effect size from the $i$ th paired trial and $n$ is the number of observations. Mean effect sizes were estimated as $\Sigma\left(M_{i} \times W_{i}\right) / \Sigma W_{i}$, with $L_{i}$ denoting the effect size from the $i$ th paired trial, and $W_{i}$ as defined above. The data were analysed using MetaWin 2.1 software. Bias-corrected 95\% confidence intervals (CIs) were calculated for each mean effect size by a bootstrapping procedure ( 4999 iterations). To ease interpretation, the results in $\ln R$ were back-transformed and reported as percentage changes under CA relative to $\mathrm{CT}$ ([R $-1] \times 100)$. Means were considered to be significantly different from one another if their $95 \%$ CIs did not overlap, and were significantly different from zero if the $95 \%$ CIs did not contain zero. Positive mean effect sizes indicate an increase in crop yield caused by CA, whereas negative values indicate a decrease.

The percentage increase (\%) of CA when compared to TT was calculated based on above method. The absolute increase $\left(\mathrm{kg} \mathrm{ha}^{-1}\right)$ of CA when compared to TT was the mean of CA's absolute increase in each paired observation (total 395 paired observations: for crops-210 for wheat, 100 maize and 85 for rice; for annual precipitation -127 for $<500 \mathrm{~mm}, 136$ for 500 $800 \mathrm{~mm}$, and 132 for $>800 \mathrm{~mm}$; for experimental durations -107 for 2-4 years, 194 for 5-9 years, and 94 for $\geq 10$ years; here, we did not analyse the factor of crop rotation due to the data limitation of current published papers) (see Supplementary material).

\subsubsection{Relationship between changes in yield and SOC under CA}

We used the same published data as used for the meta-analysis to compare data on yields and SOC. Here, only these papers which investigated the effects of CA on crops yields and soil organic matter/carbon were used; so we identified 22 papers with 34 datasets. The durations of the experiments described in these selected papers range from 2 to 17 years. Data at the end of the experiment were used to calculate the changes of SOC and crops yields in CA when compared with TT.

Soil organic matter (SOM) data were converted to SOC by the following equation:

$$
\mathrm{SOC}=\mathrm{SOM} / 2
$$


Changes to SOC and Yield were calculated by

$$
\begin{gathered}
\text { Change }_{\mathrm{SOC}}=\mathrm{SOC}_{\mathrm{CA}}-\mathrm{SOC} \mathrm{C}_{\mathrm{TT}}, \\
\text { Change }_{\text {Yield }}=\text { Yield }_{\mathrm{CA}}-\text { Yield }_{\mathrm{TT}} .
\end{gathered}
$$

The full methodology and references are contained in the Supplementary materials file.

\subsection{Impacts of $\mathrm{CA}$ in China}

\subsubsection{Agricultural productivity}

It has been observed that the potential contribution of NT (the original and central concept of CA) to productivity is limited (Pittelkow et al., 2015a, 2015b), though $60 \%$ of the plot observations in these studies were from USA and Canada. In contrast, both long-term studies and data from the field research in China show that cereal productivity can increase with CA. For example, in North China, 15-year mean winter wheat yield under CA was $18.8 \%$ higher at $3.61 \mathrm{t} \mathrm{ha}^{-1}$ compared with $3.04 \mathrm{t} \mathrm{ha}^{-1}$ for traditional tillage (Li et al., 2007), and yield increases of $9 \%$ for wheat (to $4.8 \mathrm{tha}^{-1}$ ) and $9 \%$ for summer maize (to $10.1 \mathrm{tha}^{-1}$ ) were observed (He et al., 2011).

We have conducted a meta-analysis of published research on CA in China (papers in both Chinese and English). The dataset of 60 papers included 75 paired trials and 395 observations, and allowed disaggregation of effects by crop (wheat, maize and rice), annual precipitation $(<500 \mathrm{~mm}, 500-800 \mathrm{~mm},>800 \mathrm{~mm})$ and experimental duration $(2-4,5-9, \geq 10$ years $)$ (Figure 3).

Our analysis shows that the greatest yield increases occurred in maize and in dryland zones, with yield increases the greatest in the longest duration studies. The mean increase in yields by $>4.8 \%$ is observed for all zones and durations $\left(4.5 \%\right.$ or $263 \mathrm{~kg} \mathrm{ha}^{-1}$ wheat, $8.3 \%$ or $424 \mathrm{~kg} \mathrm{ha}^{-1}$ maize, $1.7 \%$ or $250 \mathrm{~kg} \mathrm{ha}^{-1}$ rice) and the difference between any two categories was not significant. The mean increase in yields for all crops with CA practised for $\geq 10$ years is $>7.0 \%$ (394 $\mathrm{kg} \mathrm{ha}^{-1}$ ), indicating that productivity continues to increase as the natural capital of the system is enhanced over time.

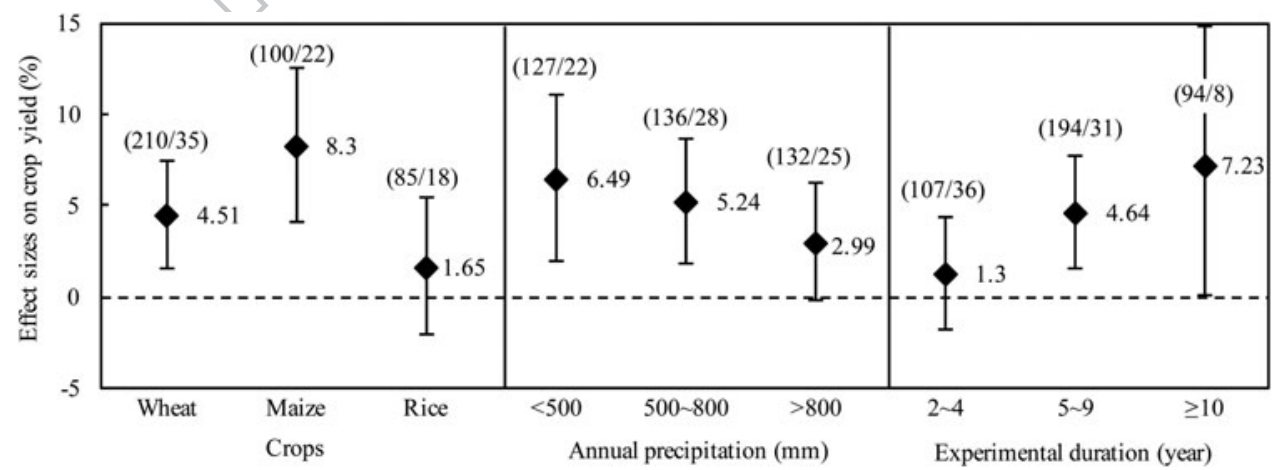

Figure 3. Effect size of CA on crop yields in China (three durations: $2-4$ years, 5-9 years and $\geq 10$ years). Notes: The corresponding value of the rhombus to the vertical axis is the rate of change in relative yield; bars show $95 \%$ bias confidence intervals; numbers of observations and experiments are indicated in parentheses. Articles in Chinese were collected from the Chinese Journal Net full-text database (CJFD), and those in English were from the Science Citation Index of the Institute for Scientific Information. In total, 60 published papers were included, consisting of 75 paired trials and 395 observations. 
Based on these findings, we conclude that the long-term use of CA in China could increase agronomic yields by $2-8 \%$ compared with that of traditional tillage. In conjunction with a reduction in the use of machinery and labour, CA could increase mean profit margins by > US $\$ 140 \mathrm{ha}^{-1} \mathrm{yr}^{-1}$. We find that application of CA on $60 \%$ (based on CA's adoption area in the main countries, such as Australia, Canada, Brazil, which have developed CA systems) of wheat-maize system in China could increase annual production by $4.0 \mathrm{Mt}$ of wheat, 4.9 Mt of maize, with an annual economic benefit of over US\$5.0 billion, resulting in an important contribution to domestic food security.

\subsubsection{Erosion control, moisture conservation and WUE}

The area of land prone to accelerated soil erosion in China is estimated to be 165 Mha by water and 191 Mha by wind. The most severe erosion occurs in the 7.8 Mha of the Yellow River Basin, where annual soil erosion rates are 50-300 tha ${ }^{-1}$ (MOWR, 2002). Conversion to $\mathrm{CA}$ could reduce the transport of wind-blown sediment and wind erosion by $>30 \%$ compared with that from ploughed land (Table 5). Adoption of CA in North China (on approximately 60 Mha arable land) could reduce annual wind-blown sediment by $\sim 50 \%$ from $6.7 \mathrm{Gt}$ (including $0.09 \mathrm{Gt}$ of organic matter, $6.7 \mathrm{Mt} \mathrm{N}$ and $1.0 \mathrm{Mt} \mathrm{P}$ ) to 3.5 Gt (Li, Gao, Feng, Wang, \& Du, 2005). Adoption of CA could also reduce water runoff and erosion by $>40 \%$ (Table 5 ), with attendant reduction in sediment and sediment-borne contaminants producing beneficial reductions in surface water eutrophication (Le et al., 2010).

By reducing losses through runoff and evaporation, conversion to CA increases soil moisture holding capacity and enhances WUE. In comparison with traditional tillage, CA can increase soil water-holding capacity by $>3 \%$ and WUE by $>10 \%$ for most crops and agro-ecoregions (Table 5). Owing to high evaporation losses under tillage, farmers must rely on rainfall or supplemental irrigation to obtain satisfactory yields. CA can also reduce water requirements, increase stream flow and also recharge the groundwater; during years of serious drought, CA conserves soil moisture and sustains production (Li et al., 2007).

Table 5. Impact of CA on erosion control and moisture conservation, China.

\begin{tabular}{|c|c|c|c|c|}
\hline$V$ & \multicolumn{3}{|c|}{ North China } & \multirow[b]{2}{*}{$\begin{array}{l}\text { South } \\
\text { China }\end{array}$} \\
\hline & $\begin{array}{l}\text { Northeast } \\
\text { China }\end{array}$ & $\begin{array}{l}\text { North China } \\
\text { Plain }\end{array}$ & $\begin{array}{l}\text { Northwest } \\
\text { China }\end{array}$ & \\
\hline \multicolumn{5}{|l|}{ Erosion reduction } \\
\hline Wind & -37 to $99 \%$ & -34 to $37 \%$ & nd & nd \\
\hline Water & -71 to $98 \%$ & $-40 \%$ & nd & $-\sim 60 \%$ \\
\hline $\begin{array}{l}\text { Water-holding capacity } \\
\text { improvement }\end{array}$ & $+3 \%$ to $12.6 \%$ & nd & $-\sim 3 \%$ & nd \\
\hline \multicolumn{5}{|l|}{ Water use efficiency increase } \\
\hline Maize & +24.3 to $28.5 \%$ & $+9 \%$ & $+7.3 \%$ & nd \\
\hline Wheat & nd & $+10.4-17.4 \%$ & $+5.9-17.5 \%$ & nd \\
\hline Oats & nd & $+16.7 \%$ & nd & nd \\
\hline Peas & nd & & $+13.3 \%$ & nd \\
\hline
\end{tabular}

Notes: Data are changes from conservation agriculture compared with traditional tillage; nd = no data. Sources: Blanchart et al. (2004), He et al. (2008, 2009, 2010), Huang et al. (2008), Jiang, Han, Zou, and Yang (2012), Li, (2009), Li et al. (2007), Wang et al. (2008, 2011, 2014), Yan, Xue, and Zhu (2009), Yu and Zhang (2007), and Zhang, Wu, Zhao, Zhang, and Cheng (2011a, 2011b). 


\subsubsection{Soil carbon}

Adotion of CA is also important for the restoration of soil quality by reducing the loss of SOC stock and improving soil microbial biomass carbon. Continuous use of CA in China has increased $\mathrm{SOM}$ in the surface layer at the rate of $0.01 \%$ per year (Barzman et al., 2004; He et al., 2011; Li et al., 2007). Such an increase is often observed after long-term ( $>10$ years) application of CA, with the magnitude of increase as much as $>2.0 \mathrm{~g}_{\mathrm{kg}} \mathrm{kg}^{-1}$ in the $0-10 \mathrm{~cm}$ layer (He et al., 2009, 2011; Li et al., 2007). Increase in SOC concentration and biotic activity reduces soil bulk density, improves pore size distribution and increases soil fertility (He et al, 2009, 2012; Li et al., 2007, 2014). Improvement in soil structure under CA mitigates soil degradation and reduces the loss of cropland, decreases emissions of methane, and creates a positive soil $\mathrm{C}$ budget particularly, in highly erodible soils (Pan et al., 2009).

We used the same published data as used for the meta-analysis to compare paired data on yields and SOC concentration (0-20 cm soil depth) (Figure 4). In 34 datasets, 26 (76.5\%) showed that CA increased both yields and SOC (CY quadrant in Figure 4) when compared to traditional tillage, and there were no cases of both reductions in yield and SOC. In all the datasets, CA showed increased SOC, and particularly in $0-10 \mathrm{~cm}$ soil depth, the mean increase could be $>3 \mathrm{gkg}^{-1}$.

We estimate that the SOC sink capacity of China's farmland could be increased by 70 $250 \mathrm{~kg} \mathrm{C} \mathrm{ha}^{-1} \mathrm{yr}^{-1}$ through conversion to $\mathrm{CA}$ systems (Table 6). Combined with reductions in fossil-fuel consumption associated with reduced ploughing, increases of SOC in CA are equivalent to $89-269 \mathrm{~kg} \mathrm{C} \mathrm{ha}^{-1} \mathrm{yr}^{-1}$, amounting to an annual increase of $7.2-21.8 \mathrm{Mt} \mathrm{C}(0.02-0.07 \mathrm{Gt}$ $\mathrm{CO}_{2} \mathrm{e}$ ) from $60 \%$ of China's farmland (Table 6). Adoption of CA would thus produce a contribution to climate change mitigation, though not as much as had been proposed in the UNEP Emission Gap report (UNEP, 2014). Our estimate here of the $\mathrm{CO}_{2}$ emission reduction through adoption of CA (0.04-0.13 $\mathrm{Gt} \mathrm{CO}_{2} \mathrm{e} \mathrm{yr}^{-1}$ ) would amount to between $1 \%$ and $6 \%$ of total global emissions

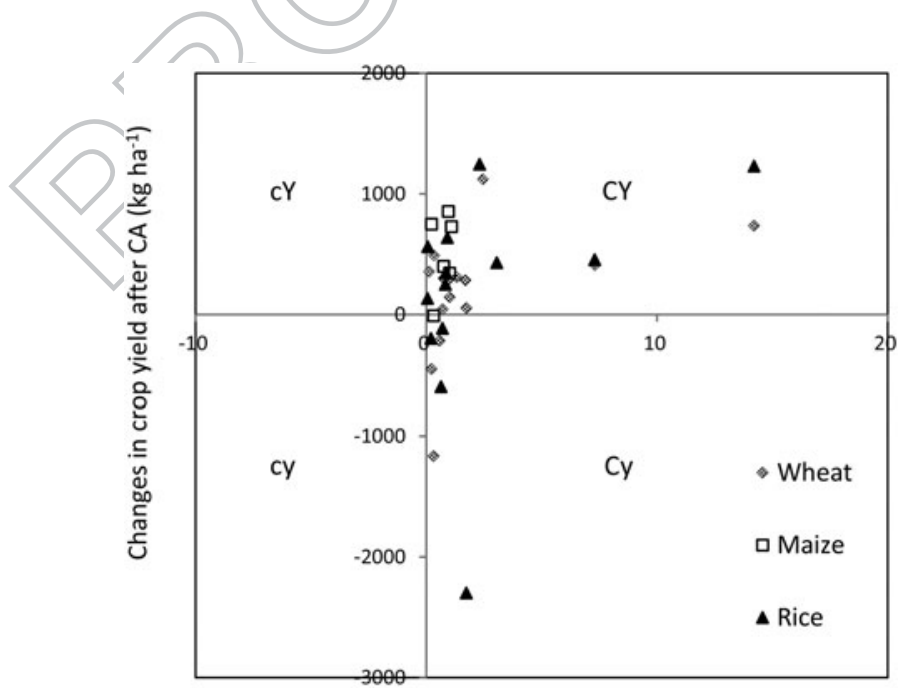

Figure 4. Relationship between changes in yield and soil organic carbon under conservation agriculture, China.

Notes: $\mathrm{CY}$ - top right: both organic carbon and yields increase; $\mathrm{Cy}$ - bottom right: organic carbon increases but yields decline; cy - bottom left: both organic carbon and yields fall; cY - top left: organic carbon declines, but yields increase. Soil organic carbon $(0-20 \mathrm{~cm}$ soil depth) and crop yields were measured at the end of each experiment. 
from adoption of CA. This would contribute to the COP-21 recommendation regarding the societal value of carbon and the need for targets for carbon sequestration in soils (Lal 2014).

\section{Policy priorities for $\mathrm{CA}$ in China}

Our findings show that CA can make a contribution to both food and environmental security in China. The greatest yield increases are for maize, followed by wheat and then rice. Yet, only $5 \%$ of total cultivated area in China is managed under CA. The potential food and environmental benefits of CA are not yet fully comprehended by most farmers, land managers and policy-makers. CA on its own, though, does not result in sufficiently great increases in yields to meet increased food requirements by mid-century. A wider SI of agro-ecosystems could bring synergistic benefits, particularly with attention paid to IPM, agroforestry systems, cover cropping, rotational grazing and crop/livestock improvements (Pretty \& Bharucha, 2014). With current trends, we expect CA to continue to be adopted, though not fast enough to provide national benefits to environmental services and agricultural outputs. We $420 \quad$ propose four national priorities.

\subsection{National policy and financial support}

A number of policy changes have recently been adopted that may lead to increases in adoption of SI and particularly CA in China. The government's 2013 No 1 Document underlined national food and nutritional security as its primary task, and set out a plan to promote the agroenvironment. In 2014, the China Ministry of Agriculture issued a Pesticide and Fertilizer Use Zero Increase Action Plan. Further opportunities are contained in The Work Plan for Greenhouse Gases Emission Control During the 12th Five-Year Plan Period in which the main objectives for control of GHG emissions are outlined. Although the total financial support available from gov-

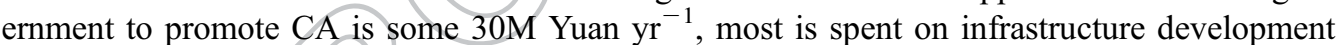
rather than research and extension. In the long term, China should adopt a policy of payments to farmers for provisioning of ecosystem services: an appropriate compensation to farmers and land managers would be the societal value of soil carbon at $\sim$ US $\$ 120$ per tonne of carbon sequestered (Pan et al., 2009).

\subsection{Better coordination across agencies}

Many agencies are involved in the research, demonstration and extension of CA in China. The Ministry of Agriculture spearheads the demonstration and implementation of CA, the Ministry of Science and Technology supports research, and the assessment of CA benefits is under the

Table 6. The effect of CA on soil carbon improvement in China relative to conventional practices.

\begin{tabular}{lc}
\hline Factor & $\begin{array}{c}\text { Impact on carbon balance } \\
\text { (conservative annual values) }\end{array}$ \\
\hline Fossil-fuel use reduction $\left(20 \mathrm{~kg} \mathrm{ha}^{-1}\right)$ & $\sim 18.8 \mathrm{~kg} \mathrm{C}-\mathrm{e} / \mathrm{ha}$ \\
Soil C sequestration & $70-250 \mathrm{~kg} \mathrm{C} / \mathrm{ha}$ \\
Total & $88.8-268.8 \mathrm{~kg} \mathrm{C} / \mathrm{ha}$ \\
\hline
\end{tabular}

Notes: Assuming 60\% (based on CA's adoption area in the main countries, such as Australia, Canada, Brazil, which have developed CA systems) Chinese farmland (total 135 Mha in 2013) is converted to CA, the estimate of the total potential of $\mathrm{C}$ sequestration in China cropland can be increased by $7.2-21.8 \mathrm{Mt} \mathrm{C}\left(0.02-0.07 \mathrm{Gt} \mathrm{CO}_{2}\right.$-e)/year. Sources: DAMM (2012); Dong, Hu, Chen, and Zhang (2009); Liu et al. (2014). 
auspices of the Ministry of Environmental Protection (MEP). We propose that a special CA coordination office be established across agencies (central and local) and sectors (e.g. agriculture, engineering and environmental protection) to promote adoption of $\mathrm{CA}$ in China. Competitive grant funds should be earmarked with financial support from Central, Provincial, civic organizations and the private sector (industry) for pursuing site-specific and long-term ( $>5 \mathrm{yr})$ research and outreach on CA.

\subsection{Locally applicable scientific research}

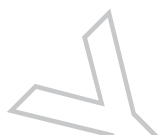

Several constraints to adoption of CA (e.g. lack of high-performance NT seeders, low agronomic yields in some situations) will have to be alleviated for large-scale implementation. Site-specific technical modes for typical cropping regions must be developed. Establishing national and local research institutions and interdisciplinary teams (including engineers, agronomists, enterprise and extension specialists), organized by the government and funded by the specific research projects through the special CA coordination office, is essential to developing site-specific CA packages (Zhang et al., 2014).

\subsection{Better extension and training for farmers}

CA can appear counter-intuitive to some farmers: it is founded on the principle of removal of the long tradition of ploughing. CA has already been adopted across the entire Beijing rural area since 2008 through the joint effort of extension, training and incentivizing mechanisms. Some farmers who recognise erosion problems and climate/weather threats will be ready to adopt CA. Many, though, will need sustained support (Derpsch, Lange, Birbaumer, \& Moriya, 2015). National/ local CA advisory centres and CA monitoring sites (for the assessment of CA's short/longterm benefits or hindrances) should be established for training and technical support. In addition to training technicians and farmers, technical support should be provided through established national/local CA advisory centres and CA monitoring sites, while seeking to establish ways to reward farmers through payments for ecosystem services. In 2014, the China central government launched a 17 billion Yuan incentive programme for the purchase of agricultural machinery: we suggest $10-15 \%$ of the budget be used for research (as an investment in a scientific project) and farmers' purchase (as a subsidy) of CA equipment.

\section{Conclusions}

CA systems have been adopted in many agro-ecosystems worldwide, bringing benefits to farmers and ecosystems. In China, compared with traditional tillage, long-term use of CA could increase WUE by $5-10 \%$, reduce wind and water erosion by $>30 \%$, and enhance SOC by $>3 \mathrm{gkg}^{-1}(0-10 \mathrm{~cm}$ soil depth). Growth in China has been encouraging in recent years, but there remains a great potential for substantial benefits to be delivered at national scale. On its own, CA would not deliver the required increase in food production by 2040-2050: we estimate between $2 \%$ and $8 \%$ yield increases over that period. There will thus need to be additional and complementary adoption of other approaches to the SI of agriculture. China has made important policy and practice reforms that support the expansion of $\mathrm{CA}$, but priorities for financial, technical and institutional support remain in research, extension and training. The positive effects of CA have been demonstrated, and now the primary agricultural goal is to increase productivity whilst improving both natural capital and ecosystem services. 


\section{Acknowledgements}

The authors thank four anonymous reviewers for the helpful comments on both the paper and supplementary materials. We also thank the Associate Editor of IJAS, Colin Sage, for handling the paper, commissioning reviews, and coming to a decision.

\section{Disclosure statement}

No potential conflict of interest was reported by the authors.

\section{Supplementary material}

Full details of sources for figures and all published papers used in the analyses are listed in the supplementary material.

Supplemental data for this article can be accessed at [10.1080/14735903.2016.1170330]

\section{References}

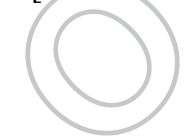

Barzman, M., Bertschinger, L., Dachbrodt-Saaydeh, S., Graf, B., Jensen, J. E., Joergensen, L. N., ... Sattin, M. (2014). Integrated pest management: Experiences with implementation, global overview. Dordrecht, NL: Springer.

Bharucha, Z. P. (2014). The Brazil-China soy complex: A global link in the food-energy-climate change trilemma. CRESI Working Paper, Colchester: University of Essex.

Blanchart, E., Albrecht, A., Brown, G., Decaens, T., Duboissete, A., Lavellee, P., \& Marianie, L. (2004). Effects of tropical endogeic earthworms on soil erosion. Agriculture, Ecosystems \& Environment, $104,303-315$.

Conway, G. R. (1997). The doubly green revolution. London: Penguin.

Costanza, R., de Groot, R. S., Sutton, P., van der Ploeg, S., Anderson, S. J., Kubiszewski, I., . . Turner, R. K. (2014). Changes in the global value of ecosystem services. Global Environmental Change, 26, 152 158.

DAMM. (2012). Study on the technology of energy-saving and emission-reducing of agricultural mechanization. Beijing: China Agricultural Science and Technology Press.

Derpsch, R., Lange, D., Birbaumer, G., \& Moriya, K. (2015). Why do medium-and large-scale farmers succeed practicing CA and small-scale farmers often do not? - experiences from Paraguay. International Journal of Agricultural Sustainability. doi:10.1080/14735903.2015.1095974

Dong, W. X., Hu, C. S., Chen, S. Y., \& Zhang, Y. M. (2009). Tillage and residue management effects on soil carbon and $\mathrm{CO} 2$ emission in a wheat-corn double-cropping system. Nutrient Cycling in Agroecosystems, $83,27-37$.

Ellis, E. C., \& Wang, S. M. (1997). Sustainable traditional agriculture in the Tai lake region of China. Agriculture, Ecosystems \& Environment, 61, 177-193.

FAO. (2015). FAOSTAT. Rome, Italy.

FAO. (2016). Save and Grow: Maize, Rice and Wheat. Rome, Italy.

Foresight. (2011). The future of global food and farming. Government office for science. London: UK Government Office for Science.

Garnett, T., Appleby, M. C., Balmford, A., Bateman, I. J., Benton, T. G., Bloomer, P., ... Godfrey, H. J. (2013). Sustainable intensification in agriculture: Premises and policies. Science, 341, 33-34.

Giller, K. E., Corbeels, M., Nyamangara, J., Triomphe, B., \& Affholder, F. (2011). A research agenda to explore the role of conservation agriculture in African smallholder farming systems. Field Crops Research, 124, 468-472.

Godfray, H. J. C., Beddington, J. R., Crute, I. R., Haddad, L., Lawrence, D., Muir, J. F., .. Toulmin, C. (2010). Food security: The challenge of feeding 9 billion people. Science, 327, 812-818.

He, J., Kuhn, N. J., Zhang, X. M., Zhang, X. R., \& Li, H. W. (2009). Effects of 10 years of conservation tillage on soil properties and productivity in the farming-pastoral ecotone of Inner Mongolia, China. Soil Use Manage, 25, 201-209. 
He, J., Li, H. W., McHugh, A. D., Ma, Z. M., Cao, X. H., Wang, Q. J., .. Zhang, X. R. (2008). Spring wheat performance and water use efficiency on permanent raised beds in arid northwest China. Australian Journal of Soil Research, 46, 659-666.

He, J., Li, H. W., Rasaily, R. G., Wang, Q. J., Cai, G. H., Su, Y. B., . . Liu, L. J. (2011). Soil properties and crop yields after 11 years of no tillage farming in wheat-maize cropping system in North China Plain. Soil and Tillage Research, 113, 48-54.

He, J., Li, H. W., Wang, Q. J., Gao, H. W., Li, W. Y., Zhang, X. M., \& McGiffen, M. (2010). The adoption of conservation tillage in China. Annals of the New York Academy of Sciences, 1195, E96-E106.

He, J., McHugh, A. D., Li, H. W., Wang, Q. J., Li, W. Y., Rasaily, R. G., \& Li, H. (2012). Permanent raised beds improved soil structure and yield of spring wheat in arid north-western China. Soil Use and Management, 28, 536-543.

Huang, G. B., Zhang, R. Z., Li, G. D., Li, L. L., Chan, K. Y., Heenan, D. P., .. Bellotti, W. D. (2008). Productivity and sustainability of a spring wheat-field pea rotation in a semi-arid environment under conventional and conservation tillage systems. Field Crops Research, 107, 43-55.

Jiang, H., Han, X. Z., Zou, W. X., \& Yang, C. B. (2012). Effect of short-term no-tillage on soil water physical property of soybean field in black soil zone. Soybean Science, 31, 374-380.

Kassam, A., Friedrich, T., Shaxson, F., Bartz, H., Mello, I., Kienzle, J., \& Pretty, J. (2014). The spread of Conservation Agriculture: policy and institutional support for adoption and uptake. Field Actions Science Reports Vol 7, http://factsreports.revues.org/3720

Kassam, A., Friedrich, T., Shaxson, F., \& Pretty, J. (2009). The spread of conservation agriculture: Justification, sustainability and uptake. International Journal of Agricultural Sustainability, 7, 292-320.

Kirkegaard, J. A., Conyers, M. K., Hunt, J. R., Kirkby, C. A., \& Watt, M. (2014). Sense and nonsense in conservation agriculture: Principles, pragmatism and productivity in Australian mixed farming systems. Agriculture, Ecosystems \& Environment, 187, 1-10.

Lal, R. (2014). Societal value of soil carbon. Journal of Soil and Water Conservation, 69, 186A-192A.

Lal, R. (2015a). A system approach to conseryation agriculture. Journal of Soil and Water Conservation, 70, $82 \mathrm{~A}-88 \mathrm{~A}$.

Lal, R. (2015b). Sequestering carbon and increasing productivity by conservation agriculture. Journal of Soil and Water Conservation, 70, 55A-62A.

Lal, R., Griffin, M., Apt, J., Lave, L., \& Morgan, M. G. (2004). Managing soil carbon. Science, 304, 393.

Le, C., Zha, Y., Li, Y., Sun, D., Lu, H., \& Yin, B. (2010). Eutrophication of lake waters in China: Cost, causes, and control. Environmental Management, 45, 662-668.

Li, C. Y. (2009). Soil water-holding capacity under different tillage practices and effect factors (Master dissertation). Gansu Agricultural University, Lanzou, China.

Li, H., Wang, Q. J., He, J., Li, H. W., Lu, Z. Y., Rasaily, R. G., ... Zheng, Z. Q. (2014). Permanent raised beds improved soil physical properties in an annual double-cropping system. Agronomy Journal, 106, $7-14$.

Li, H. W., Gao, H. W., Feng, X. J., Wang, X. Y., \& Du, B. (2005). Contribution of farmland wind erosion to sand storms in northern China. Proceedings of SPIE-The International Society for Optical Engineering: Remote Sensing and Modeling of Ecosystems for Sustainability II, San Diego, USA.

Li, H. W., Gao, H. W., Wu, H. D., Li, W. Y., Wang, X. Y., \& He, J. (2007). Effects of 15 years of conservation tillage on soil structure and productivity of wheat cultivation in northern China. Australian Journal of Soil Research, 45, 344-350.

Liu, E. K., Teclemariam, S. G., Yan, C. G., Yu, J. M., Gu, R. S., Liu, S., ... Liu, Q. (2014). Long-term effects of no-tillage management practice on soil organic carbon and its fractions in the northern China. Geoderma, 213, 379-384.

Lu, Y. L., Chadwick, D., Norse, D., Powlson, D., \& Shi, W. M. (2015). Sustainable intensification of China's agriculture: The key role of nutrient management and climate change mitigation and adaptation. Agriculture, Ecosystems \& Environment, 209, 1-4.

Lundy, M. E., Pittelkow, C. M., Linquist, B. A., Liang, X., \& van Groenigen, K. J. (2015). Nitrogen fertilization reduces yield declines following no-till adoption. Field Crops Research, 183, 204-210.

Mendes, R., Kruijt, M., de Bruijn, I., Dekkers, E., van der Voort, M., Schneider, J. M., ... Raaijmakers, J. M. (2011). Deciphering the rhizosphere microbiome for disease-suppressive bacteria. Science, 332, $1097-$ 1100.

Ministry of Agriculture (MOA). (2000-2014). China agricultural mechanization statistical yearbook. Beijing, China.

Ministry of Agriculture (MOA). (2014). China agricultural mechanization statistical yearbook. Beijing, China. 
Ministry of Environmental Protection (MOEP). (2014). Bulletin of Chinese environmental status. Beijing, China.

Ministry of Land and Resources (MOLR). (2010-2014). Bulletin of Chinese land resources. Beijing, China. Ministry of Water Resources (MOWR). (2002). The second national remote-sensing survey. Beijing, China. Ministry of Water Resources (MOWR). (2013). Bulletin of Chinese soil and water conservation. Beijing, China.

National Bureau of Statistics (NBS). (2013). China rural statistic yearbook. Beijing: China Statistic Press. National Bureau of Statistics (NBS). (2014). China statistical yearbook. Beijing: China Statistic Press.

Norse, D., \& Ju, X. T. (2015). Environmental costs of China's food security. Agriculture, Ecosystems \& Environment, 209, 5-14.

Norse, D., Li, J., Jin, L., \& Zhang, Z. (2001). Environmental costs of rice production in China: Lessons from Hunan and Hubei. Bethesda: Aileen Press.

Pan, G. X., Zhou, P., Li, Z. P., Smith, P., Li, L. Q., Qiu, D. S., .. Chen, X. M. (2009). Combined inorganic/ organic fertilization enhances $\mathrm{N}$ efficiency and increases rice productivity through organic carbon accumulation in a rice paddy from the Tai Lake region, China. Agriculture, Ecosystems \& Environment, 131, 274-280.

Pittelkow, C. M., Liang, X., Linquist, B. A., van Groenigen, K. J., Lee, J., Lundy, M. E., ... van Kessel, C. (2015a). Productivity limits and potentials of the principles of conservation agriculture. Nature, 517, $365-368$.

Pittelkow, C. M., Linquist, B. A., Lundy, M. E., Liang, X. Q., van Groenigen, K. J., Lee, J., ... van Kessel, C. (2015b). When does no-till yield more? A global meta-analysis. Field Crops Research, 183, 156168.

Powlson, D. S., Stirling, C. M., Jat, M. L., Gerard, B. G., Palm, C. A., Sanchez, P. A., \& Cassman, K. G. (2014). Limited potential of no-till agriculture for climate change mitigation. Nature Climate Change, 4, 678-683.

Pretty, J. (2013). The consumption of a finite planet: Well-being, convergence, divergence and the nascent green economy. Environmental and Resource Economics, 55, 475-499.

Pretty, J., \& Bharucha, Z. P. (2014). Sustainable intensification in agricultural systems. Annals of Botany, $114,1571-1596$.

Pretty, J., \& Bharucha, Z. P. (2015). Integrated pest management for sustainable intensification of agriculture in Asia and Africa. Insects, 6, 152-182.

Royal Society. (2009). Reaping the benefits: Science and the sustainable intensification of global agriculture. London: Royal Society.

Shi, T. (2002). Ecological agriculture in China: Bridging the gap between rhetoric and practice of sustainability. Ecological Economics, 42, 359-368.

Smith, P. (2013). Delivering food security without increasing pressure on land. Global Food Security, 2, 18-23.

Su, S. L., Jiang, Z. L., Zhang, Q., \&Zhang, Y. (2011). Transformation of agricultural landscapes under rapid urbanization: A threat to sustainability in Hang-Jia-Hu region, China. Applied Geography, 31, 439-449.

Tilman, D., Balzer, C. Hill, J., \& Befort, B. L. (2011). Global food demand and the sustainable intensification of agriculture. Proceedings of the National Acadamy of Sciences, 108, 20260-20264.

UNEP. (2014). Emissions gap report. Nairobi, Kenya.

Wang, Q., Lu, C., Li, H., He, J., Sarker, K. K., Rasaily, R. G., .. McHugh, A. D. J. (2014). The effects of notillage with subsoiling on soil properties and maize yield: 12-year experiment on alkaline soils of Northeast China. Soil and Tillage Research, 137, 43-49.

Wang, X. B., Dai, K. A., Zhang, D. C., Zhang, X. M., Wang, Y., Zhao, Q. S., .. Oenema, O. (2011). Dryland maize yields and water use efficiency in response to tillage/crop stubble and nutrient management practices in China. Field Crops Research, 120, 47-57.

Wang, X. B., Oenema, O., Hoogmoed, W. B., Perdok, U. D., \& Cai, D. X. (2006). Dust storm erosion and its impact on soil carbon and nitrogen losses in northern China. Catena, 66, 221-227.

Wang, X. Y., Gao, H. W., Tullberg, J. N., Li, H. W., Kuhn, N., McHugh, A. D., \& Li, Y. X. (2008). Traffic and tillage effects on runoff and soil loss on the Loess Plateau of northern China. Australian Journal of Soil Research, 46, 667-675.

Yan, X. L., Xue, S. P., \& Zhu, R. X. (2009). Conservative tillage for soil conservation with stubble in sandstorm area along the Great Wall in North Shaanxi Province of China. Journal of Northwest $A \& F$ University, 37, 101-104.

Yu, T. Y., \& Zhang, X. Y. (2007). Effects of different soil tillage systems on soil water in the black farmland. Journal of Southwest University (Natural Science Edition), 29, 121-124. 
Yu, Y. X., Zhao, C. Y., \& Jia, H. T. (2015). Ability of split urea applications to reduce nitrous oxide emissions: A laboratory incubation experiment. Applied Soil Ecology, 100, 75-80.

Zhang, F. Y., Wu, P. T., Zhao, X. N., Zhang, E. H., \& Cheng, X. F. (2011a). Effects of conservation tillage on soil water regimes and water use efficiency in farmland of Heihe river basin in Northwest China. African Journal of Agricultural Research, 6, 5959-5966.

Zhang, H. L., Lal, R., Zhao, X., Xue, J. F., \& Chen, F. (2014). Opportunities and challenges of soil carbon sequestration by conservation agriculture in China. Advances in Agronomy, 124, 1-36.

Zhang, S. L., Zhang, X. Y., Huffman, T., Liu, X. B., \& Yang, J. Y. (2011b). Soil Loss, crop growth, and economic margins under different management systems on a sloping field in the black soil area of Northeast China. Journal of Sustainable Agriculture, 35, 293-311.

Zheng, C., Jiang, Y., Chen, C., Sun, Y., Feng, J., Deng, A., ... Zhang, W. (2014). The impacts of conservation agriculture on crop yield in China depend on specific practices, crops and cropping regions. The

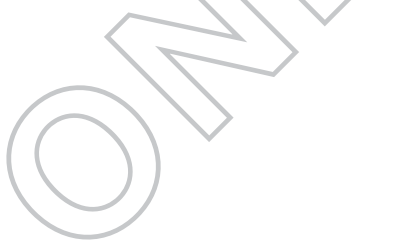

